\title{
GAMBARAN KEBERSIHAN MULUT DAN KARIES GIGI PADA VEGETARIAN LACTO-OVO DI JURUSAN KEPERAWATAN UNIVERSITAS KLABAT AIRMADIDI
}

\author{
${ }^{1}$ Michael W. Candra \\ ${ }^{2}$ Shane H. R. Ticoalu \\ ${ }^{3}$ Juliatri \\ ${ }^{1}$ Kandidat Skripsi Program Studi Pendidikan Dokter Gigi Fakultas Kedokteran \\ ${ }^{2}$ Bagian Anatomi-Histologi Fakultas Kedokteran \\ ${ }^{3}$ Program Studi Pendidikan Dokter Gigi Fakultas Kedokteran \\ Universitas Sam Ratulangi Manado \\ E-mail: akiank064@gmail.com
}

\begin{abstract}
Good oral hygiene status can support oral health. The disease of the people in community is caries. Caries occur because of a lack of awareness about oral health. The purpose of this study to determine oral health overview and dental caries on lacto-ovo vegetarian in the department of nursing at the klabat university airmadidi. The population in this study that all students lacto-ovo vegetarian status III-VII semester student with a number of 150 people. The number of samples obtained from 60 people using the Slovin formula and how sampling using purposive sampling method. This kind of research is a descriptive cross sectional study. Based on the result of the study showed 60 samples examined 24 (40\%) students who have optioned good oral hygiene, 36 (60\%) students have mild oral hygiene, and no student has bad oral hygiene. Showed caries status 38(44,19\%) students have caries, 27 (31,40\%) students whose teeth removed due to decay or other indications. And $21(24,42 \%)$ students get a permanent or temporary densities are still good. From the result about oral health overview and dental caries showed oral hygiene on lacto-ovo vegetarian in the department of nursing at the klabat university airmadidi in mild category however caries in low category.
\end{abstract}

Keywords: oral hygiene and teeth caries, lacto-ovo vegetarian

\begin{abstract}
Abstrak: Status kebersihan mulut yang baik dapat menunjang kesehatan rongga mulut. Penyakit gigi yang banyak dialami masyarakat yaitu karies. Karies terjadi karena kurangnya kesadaran seseorang untuk menjaga kebersihan rongga mulutnya. Tujuan penelitian ini untuk mengetahui gambaran kebersihan mulut dan karies gigi pada vegetarian Lacto-Ovo di jurusan keperawatan Universitas Klabat Airmadidi. Populasi pada penelitian ini yaitu seluruh mahasiswa vegetarian lacto-ovo yang berstatus mahasiswa semester III-VII dengan jumlah 150 orang. Jumlah sampel 60 orang diperoleh menggunakan rumus Slovin dan cara pengambilan sampel menggunakan purposive sampling method. Jenis penelitian ini bersifat deskriptif dengan pendekatan cross sectional study. Berdasarkan hasil penelitian menunjukkan dari 60 sampel yang diperiksa didapatkan 24 (40\%) mahasiswa yang mempunyai OHI-S baik, 36 (60\%) mahasiswa mempunyai OHI-S sedang, dan tidak ada mahasiswa yang mempunyai OHI-S buruk. Status karies menunjukkan 38 (44,19\%) mahasiswa mengalami karies, 27 (31,40\%) mahasiswa yang giginya dicabut karena karies atau indikasi lainnya, dan 21 (24,42\%) mahasiswa mendapatkan tumpatan tetap atau sementara yang masih bagus. Berdasarkan hasil penelitian tentang gambaran kebersihan mulut dan karies maka disimpulkan bahwa status kebersihan mulut pada vegetarian lacto-ovo di jurusan keperawatan Universitas Klabat Airmadidi termasuk kategori sedang sedangkan status karies termasuk dalam kategori rendah.
\end{abstract}

Kata kunci : Kebersihan mulut dan karies gigi, Vegetarian lacto-ovo

Kebutuhan gizi yang baik ditentukan oleh pola makan atau jenis makanan yang dikonsumsi seseorang. Pada umumnya pola makan yang dijalankan seseorang yaitu pola makan empat sehat lima sempurna. Pada vegetarian berkembang pola makan 
empat sehat atau dikenal dengan istilah kuartet nabati. ${ }^{1,2}$

Vegetarian atau vegetarianisme merupakan aliran kaum penganut yang tidak mengonsumsi produk-produk hewani dan turunannya. ${ }^{3}$ Banyak alasan seseorang mengubah pola makan dari semula pemakan daging menjadi vegetarian seperti alasan kesehatan, ekonomi, etika dan alasan spiritual. ${ }^{4}$ Faktor kesehatan menjadi salah satu alasan utama seseorang menjadi vegetarian. Pola makan vegetarian mengonsumsi makanan berserat dan makanan kaya karbohidrat. $^{1} \quad$ Plak merupakan faktor risiko terjadinya karies. ${ }^{5}$ Makanan nabati ternyata berdampak sangat baik bagi kesehatan umum dan menghindarkan atau mengurangi risiko berbagai penyakit degeneratif. Berdasarkan hasil penelitian Campbell, diketahui bahwa 80-90\% penyakit kanker, kardiovaskular dan penyakit degenerasi lainnya dapat dicegah sampai usia tua dengan hanya mengonsumsi makanan nabati. ${ }^{5}$ Dari aspek etika, seseorang menjadi vegetarian karena berdasarkan pada prinsip bahwa manusia semestinya menghargai hewan sebagai sesama makhluk hidup. Dalam bingkai peri kemanusiaan, hewan jangan diperlakukan semena-mena. Sikap semena-mena termasuk membunuh hewan secara keji akan berimbas pada perilaku. ${ }^{6}$ Berdasarkan berbagai alasan tersebut, seseorang melakukan vegetarian dengan berbagai tipe. Bila hanya untuk alasan kesehatan maka ia akan menjadi semi-vegetarian, yaitu pada dasarnya hanya mengurangi makan daging, ikan dan produknya. Vegetarian dengan alasan spiritual dan alasan tidak menyakiti sesama makhluk akan menerapkan vegetarian ketat (strict vegetarian). ${ }^{4}$

Survei Newspoll pada tahun 2000 melaporkan 2\% penduduk Australia ialah vegetarian dan $18 \%$ penduduk lebih menyukai makanan vegetarian. Lebih dari 50\% penduduk India pada tahun 2003 ialah vegetarian. Jumlah vegetarian yang terdaftar pada Indonesian Vegetarian Society (IVS) saat berdiri pada tahun 1998 sekitar lima ribu orang dan meningkat menjadi enam puluh ribu pada tahun 2007. Hasil survei ini menunjukkan bahwa sekarang ini pola makan vegetarian mulai semakin diminati oleh masyarakat di negara-negara maju maupun berkembang. ${ }^{7}$

Vegetarian yang berpantang daging harus mencukupi kebutuhan protein dari produk nabati seperti kacang-kacangan, sayuran berprotein tinggi, kedelai serta berbagai jenis hasil olahannya seperti tahu, tempe, dan lain sebagainya. ${ }^{3}$ Penelitian Brodribb, dkk, melaporkan bahwa rata-rata asupan serat pada vegetarian berkisar 40 gram/hari, lebih tinggi daripada asupan serat non vegetarian yang hanya berkisar

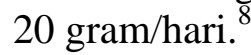

Pola makan vegetarian yang kaya akan makanan berserat dapat memengaruhi kebersihan gigi dan mulut. Menurut McDonald dan Avery, kebiasaan makan makanan berserat tidak bersifat merangsang pembentukan plak, melainkan berperan sebagai pengendali plak secara alamiah. $^{9}$ Indeks yang digunakan untuk mendapatkan data tentang status karies ialah indeks DMF-T. ${ }^{10}$

Prevalensi terjadinya karies gigi merupakan masalah klinik yang signifikan. Hasil Survei Kesehatan Rumah Tangga (SKRT) di Indonesia pada tahun 2001 diperoleh prevalensi karies pada penduduk usia 10 tahun ke atas sebesar $70 \%$ yakni pada usia 12 tahun sebesar 43,9\%, usia 15 tahun mencapai $37,4 \%$, usia 18 tahun $51,1 \%$, usia 35-44 tahun $80,1 \%$ dan usia 65 tahun ke atas mencapai $96,7 \%$. Hal ini menunjukkan suatu keadaan kerusakan gigi yang hampir tanpa penanganan.Hasil Survei Kesehatan Rumah Tangga (SKRT) tahun 2004 tingkat karies di Indonesia telah mencapai 90,05\% dari penduduk Indonesia, dan tahun 2011 angka kejadian yang paling signifikan terjadi pada usia 15 tahun $81,2 \%{ }^{11}$

Mayoritas vegetarian yang ada di Universitas Klabat Airmadidi berdomisili di dalam lingkungan universitas yang tinggal di dalam asrama dan juga koskosan. Untuk anak asrama mempunyai jadwal makan tiga kali sehari, normal seperti pola makan pada umumnya hanya 
dibedakan dengan lauk pauk mereka yang tanpa daging. Penganut vegetarian yang tinggal di kos-kosan menyesuaikan pola makan mereka juga seperti vegetarian yang ada di dalam asrama. Mayoritas vegetarian di Universitas Klabat Airmadidi di jurusan Keperawatan ini menganut tipe vegetarian Lacto-ovo yaitu vegetarian yang masih mengonsumsi turunan dari hewan ternak seperti susu dan telur. Penelitian dilakukan di Universitas Klabat dikarenakan penganut vegetarian di tempat tersebut mempunyai data dan informasi yang jelas yang membantu peneliti melakukan penelitian.

Penelitian mengenai kebersihan mulut dan karies gigi pada vegetarian di Jurusan Keperawatan Universitas Klabat Airmadidi belum pernah dilakukan, oleh karena itu peneliti tertarik untuk mengetahui bagaimana gambaran kebersihan mulut dan karies gigi pada vegetarian lacto-ovo di Universitas Klabat Airmadidi Sulawesi Utara.

\section{BAHAN DAN METODE PENELITIAN}

Penelitian ini bersifat deksriptif dengan menggunakan pendekatan desain penelitian cross sectionalstudy. Penelitian ini dilaksanakan di Jurusan Keperawatan Universitas Klabat Airmadidi pada bulan September 2014Populasi penelitian yaitu para vegetarian di Jurusan Keperawatan Universitas Klabat Airmadidi yang berjumlah 150 orang.Sampel pada penelitian ini yaitu mahasiswa usia 18-21 tahun yang ada di jurusan keperawatan Universitas Klabat Airmadidi yang memenuhi kriteria inklusi dan eksklusi. Kriteria inklusi yaitu mahasiswa yang menjalani pola makan vegetarian lacto-ovo minimal selama satu tahun,tidak sedang memakai alat orthodonti, bersedia mengikuti penelitiandan kooperatif. Kriteria eksklusi yaitu mahasiswa yang menjalani pola makan vegetarian selain tipe lacto-ovo,mahasiswa yang kehilangan seluruh gigi indeks yang akan diperiksa, mahasiswa yang mempunyai penyakit sistemik.

Metode pengambilan sampel menggunakan teknik purposive sampling method, yakni metode pengambilan sampel yang dipilih dengan cermat sehingga relevan dengan struktur penelitian. Sampel merupakan individu yang dipilih berdasarkan ciri-ciri spesifik dan memiliki karakteristik tertentu sesuai keinginan penelitidengan besar sampel yaitu 60 sampel. Variabel penelitian yaitu Mahasiswa vegetarian, kebersihan mulut dan karies gigi.

Definisi operasionalVegetarian lactoovo ialah orang yang berpantang makan daging, tetapi masih mengonsumsi sayuran dan bahan nabati lainnya dan juga turunan dari hewan seperti telur dan susu.

Kebersihan gigi dan mulut diukur menggunakan Indeks OHI-S (Green dan Vermillion). Gigi yang diperiksa ialah $\mathrm{M}_{1}$ kanan atas sisi bukal, $\mathrm{I}_{1}$ kanan atas sisi labial, $\mathrm{M}_{1}$ kiri atas sisi bukal, $\mathrm{M}_{1}$ kiri bawah sisi lingual, $\mathrm{I}_{1}$ kiri bawah sisi labial dan $\mathrm{M}_{1}$ kanan bawah sisi lingual, dengan kategori:

Skor $0-1,2=$ kebersihan mulut baik

Skor 1,3-3,0 = kebersihan mulut sedang

Skor 3,1-6,0 = kebersihan mulut buruk

Pengalaman karies diukur dengan menggunakan Indeks DMF-T menurut WHO, yaitu:

Untuk pemeriksaan DMF-T, semua gigi diperiksa kecuali gigi molar tiga karena biasanya gigi tersebut tidak tumbuh atau sudah dicabut.

$\begin{array}{ll}\text { Sangat rendah } & =0,0-1,1 \\ \text { Rendah } & =1,2-2,6 \\ \text { Sedang } & =2,7-4,4 \\ \text { Tinggi } & =4,5-6,5 \\ \text { Sangat tinggi } & =>6,6\end{array}$

\section{HASIL PENELITIAN}

Subjek pada penelitian ini berjumlah 60 sampel yang terdiri dari 24 mahasiswa laki-laki dan 36 mahasiswa perempuan dengan kisaran usia 18-21 tahun yang sedang menjalani program vegetarian lacto-ovo. Berdasarkan hasil penelitian didapatkan gambaran kebersihan mulut pada vegetarian lacto-ovo di jurusan keperawatan Universitas Klabat Airmadidi (Tabel 1, 2 dan 3) 
Tabel 1. Kriteria status kebersihan mulut Vegetarian Lacto-ovo di jurusan Keperawatan Universitas Klabat Airmadidi

\begin{tabular}{cccccc}
\hline$\sum \mathrm{n}$ & $\sum \mathrm{DI}$ & $\sum \mathrm{CI}$ & OHI-S $\left(\sum \mathrm{DI}+\sum \mathrm{CI}\right)$ & OHI-S rata-rata & kriteria \\
\hline 60 & 51,2 & 32,6 & 83,8 & 1,39 & Sedang \\
\hline
\end{tabular}

Tabel 2. Distribusi status kebersihan mulut berdasarkan jenis kelamin pada vegetarian lacto-ovo di jurusan Keperawatan Universitas Klabat Airmadidi

\begin{tabular}{lllllllll}
\hline & \multicolumn{9}{c}{ OHI-S } \\
\cline { 2 - 8 } Jenis kelamin & Baik & \multicolumn{3}{c}{ Sedang } & buruk & Total & \\
\cline { 2 - 8 } & $\mathrm{n}$ & $\%$ & $\mathrm{n}$ & $\%$ & $\mathrm{n}$ & $\%$ & $\mathrm{n}$ & $\%$ \\
\hline Laki-laki & 9 & 37,5 & 15 & 62,5 & 0 & 0 & 24 & 60 \\
Perempuan & 15 & 41,67 & 21 & 58,3 & 0 & 0 & 36 & 40 \\
\hline Total & 24 & 40 & 36 & 60 & 0 & 0 & 60 & 100 \\
\hline
\end{tabular}

Tabel 3.Status karies pada vegetarian lacto-ovo di jurusan Keperawatan Universitas Klabat Airmadidi

\begin{tabular}{cccccccccc}
\hline \multirow{2}{*}{ Jenis kelamin } & \multicolumn{2}{c}{$\mathrm{D}$} & \multicolumn{2}{c}{$\mathrm{M}$} & \multicolumn{2}{c}{$\mathrm{F}$} & \multirow{2}{*}{ Total } & \multirow{2}{*}{ DMF-T } \\
\cline { 2 - 8 } & $\mathrm{n}$ & $\%$ & $\mathrm{n}$ & $\%$ & $\mathrm{n}$ & $\%$ & $\mathrm{n}$ & $\%$ & \\
\hline Perempuan & 22 & 57,9 & 19 & 70,4 & 10 & 47,6 & 51 & 59,3 & 1,39 \\
Laki-laki & 16 & 42,1 & 8 & 29,6 & 11 & 52,4 & 35 & 40,7 & 1,17 \\
\hline Total & 38 & 44,19 & 27 & 31,40 & 21 & 24,42 & 86 & 100 & 1,43 \\
\hline
\end{tabular}

\section{BAHASAN}

Pada penelitian ini subjek yang diteliti berjumlah 60 mahasiswa vegetarian dan berada dalam kisaran umur sekitar 18-21 tahun yang berstatus mahasiswa semester III-VII. Berdasarkan hasil penelitian didapatkan paling banyak status kebersihan mulut termasuk dalam kategori sedang yaitu sebanyak 36 mahasiswa. Hal ini disebabkan pengetahuan tentang pemeliharaan kesehatan gigi dan mulut dari subjek yang diteliti masih kurang. Hal ini dapat diketahui dari beberapa pertanyaan yang diberikan peneliti. Penelitian yang sama dilakukan oleh Prawira pada vegetarian di Maha Vihara Maitreya Medan dengan hasil OHI-S rata-rata sebesar 2,20 yang didominasi kategori sedang sebanyak $64 \%$ dari 74 respondennya. $^{12}$ Hasil penelitian Steinbach menunjukkan bahwa mengonsumsi kacang-kacangan dapat membantu memperlambat produksi plak pada gigi yang berpotensi meningkatkan kebersihan mulut. ${ }^{13}$ Hal ini menunjukkan bahwa kebersihan mulut dapat juga dipengaruhi oleh faktor makanan atau nutrisi seperti mengonsumsi kacangkacangan atau makanan berserat lainnya.

Pola makan vegetarian kaya akan makanan berserat. $^{2}$ Serat dalam sayursayuran dan buah-buahan berpotensi meningkatkan kebersihan mulut, karena merupakan pembersih alamiah pada permukaan gigi. ${ }^{14}$ Menurut Krasse dan Newburn, sayuran dan buah-buahan berserat dan berair akan bersifat membersihkan karena harus dikunyah dan dapat menstimulus sekresi saliva. Makanan yang bersifat membersihkan gigi merupakan gosok gigi alami dan mengurangi kerusakan gigi, sebaliknya makanan yang bersifat lunak dan melekat sangat merusak gigi. Serat dalam sayursayuran dan buah-buahan merupakan 
pembersih alamiah pada permukaan gigi geligi, membantu menyingkirkan partikelpartikel makanan dan gula selama proses mengunyah. ${ }^{15}$ Kebiasaan makan makanan berserat tidak bersifat merangsang pembentukan plak melainkan berperan sebagai pengendali plak secara alamiah. ${ }^{1}$ Penulis berasumsi bahwa semua faktor di atas mungkin menjadi penyebab rendahnya nilai OHI-S rata-rata pada vegetarian.

Berdasarkan hasil penelitian pada tabel 2 didapatkan skor DMF-T rata-rata sebesar 2,56 yang termasuk dalam kategori sedang. Kebersihan mulut merupakan faktor risiko dari karies, sehingga nilai OHI-S yang rendah mungkin menyebabkan nilai DMFT yang lebih rendah dan sebaliknya. ${ }^{16}$ Dalam penelitian ini didapatkan juga beberapa vegetarian yang mengonsumsi gluten/daging tiruan yang mengandung kadar karbohidrat tinggi tapi disayangkan tidak dikonsumsi seluruh vegetarian hanya didapatkan sekitar $\pm 5 \%$ dari populasi yang diteliti sehingga tidak dapat dijadikan suatu tinjauan dalam penelitian ini. Menurut Chandra, epidemik karies dipengaruhi oleh tiga faktor salah satunya faktor subsrat seperti nutrisi dan makanan. Nutrisi yang diperoleh dari makanan yang dikonsumsi sehari-hari memberikan efek sikat gigi secara alami sehingga menstimulus produksi saliva dalam mulut dan mengurangi risiko karies. ${ }^{17}$

Dari pernyataan tersebut mendukung adanya hubungan pola makan yang digunakan vegetarian lacto-ovo ini dengan status kebersihan mulut yang memengaruhi nilai DMFT dari subjek yang diteliti. Menurut Nasarudin, makanan yang dikonsumsi vegetarian seperti kacangkacangan dan sayur-sayuran dapat menstimulus aliran saliva yang menetralkan keasaman dalam rongga mulut yang dapat menghambat terjadinya karies. ${ }^{18}$ Makanan berserat yang banyak dikonsumsi oleh vegetarian ini membantu proses sikat gigi secara alami sehingga tidak menutup kemungkinan jika status DMFT dari vegetarian lebih baik dari pada non vegetarian.
Faktor lainnya seperti lingkungan tempat tinggal juga dapat memengaruhi terjadinya karies. Letak geografis dari Universitas Klabat Airmadidi berada pada daerah pegunungan yang kandungan mineral dalam air yang mereka konsumsi mengandung banyak fluor. Fluor telah dikenal sebagai salah satu unsur yang dapat mencegah karies. Hal ini dikuatkan oleh penelitian Wiratmo tentang kejadian karies pada masyarakat yang tinggal di daerah pantai dan daerah pegunungan pada tahun 2008 yang menyatakan masyarakat yang tinggal di daerah pegunungan memiliki karies yang lebih sedikit dibandingkan masyarakat yang tinggal di daerah pantai, hal ini dipengaruhi oleh air minum yang dikonsumsi di daerah pegunungan mengandung banyak fluor serta konsumsi makanan mereka. ${ }^{19}$ Pernyataan tersebut membuat peneliti berasumsi bahwa status karies yang dialami vegetarian lacto-ovo ini bukan hanya dipengaruhi oleh jenis makanan yang dikonsumsi melainkan juga jenis minuman yang mereka konsumsi sehari-hari. Para vegetarian ini dapat menyeimbangkan kebutuhan dalam tubuh mereka terlebih lagi pada rongga mulut mereka tinggal di daerah pegunungan yang air di daerahnya mengandung mineral fluor yang cukup dan didukung dengan makanan berserat yang membantu sikat gigi secara alami.

Berdasarkan hal tersebut bahwa penyebab rendahnya skor DMF-T pada vegetarian lacto-ovo di jurusan Keperawatan Universitas Klabat Airmadidi ini disebabkan gizi dari makanan dan kandungan mineral dari air yang sehari hari dikonsumsi mereka yang dapat memperlambat terjadinya karies.

\section{SIMPULAN}

Berdasarkan hasil penelitian tentang gambaran kebersihan mulut dan karies maka disimpulkan bahwa status kebersihan mulut pada vegetarian lacto-ovo di jurusan keperawatan Universitas Klabat Airmadidi termasuk kategori sedang sedangkan status karies termasuk dalam kategori rendah. 


\section{SARAN}

Bagi Institusi untuk perlu membuat program pelayanan kesehatan khususnya di bidang gigi dan mulut dengan perencanaan yang baik serta melengkapi sarana dan prasarana untuk menunjang program tersebut sehingga persentase status karies dan status kebersihan mulut pada mahasiswa Universitas Klabat khususnya di Jurusan Keperawatan semakin rendah dan baik. Sebaiknya setiap enam bulan sekali wajib memeriksakan ke dokter gigi mengenai kesehatan gigi dan mulut.

Bagi Pemerintah hasil penelitian berupa data mengenai kebersihan mulut dan karies pada vegetarian lacto-ovo yang dapat dijadikan sebagai dasar dalam pembuatan program untuk mengoptimalkan upaya pencegahan terhadap penyakit mulut.

\section{DAFTAR PUSTAKA}

1. Chemiawan E, Gartika M, Saptarini PR. Perbedaan tingkat kebersihan gigi dan mulut antara anak Vegetarian dan non vegetarian di Vihara Maitreya Pusat Jakarta. Jurnal Kedokteran Gigi Indonesia Edisi Khusus PIN IKGA II 2007.p.79-84.

2. Linan L. Vegetarian OK dengan kuartet nabati. Yogyakarta: Penerbit Maitreyawira, 1997.p. 55-63.

3. Nurheti Y. Pilih vegetarian atau non vegetarian? Plus minus pilihan anda dari segi kesehatan. Jakarta: Penerbit PT Gramedia Pustaka Utama; 2008.p. 1,3,54-60,70-85.

4. Wardhana M. Vegetarian dana spek kesehatan. 2007. Available from: $<$ http://www.bvinstitute. org/index.php> (diakses Agustus 2009).

5. Widjaja H. Keuntungan aspek kesehatan vegetarian. South East Asian vegetarian congress 2008.p. 21.

6. Prasetyo AL. Vegetarian, sekarang jadi gaya hidup. Available from: <http://kompas.co.id/read/xml/2008/07/ 10/19505483/vegetarian.sekarang.jadi. gaya.hidup>(diakses September 2009).

7. Susianto, Nurheti Y. Survei Anak Vegetarian di Indonesia. Jakarta: Indonesia Vegetarian Society (IVS);
2007. Availble from:

$<$ http://www.ivs_online.com>

8. Brodribb AJM. Dietary fibre as a tool of the clinician. In: Birch GG, Parker KJ. Dietary Fibre. England: Applied Science Publishers; 1983. p. 202.

9. McDonald, Avery. Dentistry For The Child and Adolescent. International Journal; 2010. p. 22.

10.Daliemunthe SH. Terapi periodontal. Medan: Bagian Periodonsia FKG USU; 2006.p. 127.

11.Handini A. Perbedaan efek topikal aplikasi bahan casein phosphopeptide. Makassar : UNHAS; 2013.p. 3.

12.Prawira A. Kondisi Oral hygiene dan karies gigi pada vegetarian di maha vihara maitreya. Medan: USU: 2010.p. 23

13.Nancy S. Science report - Dental health. 2003. Available from: <http://www.1 Language.com/

eslnews/science021126.htm> (diakses Januari 2010).

14.Tan C. Vegetuslibertas: Bagas raga, waras spirit, kuat budi; 2009.availble from: $<$ http://onlyoneearth.wordpress.com/20 09/06/26/vegetus-libertas-bagas-tubuhwaras-budi/>(diakses September 2009).

15.Krasse E, Newburn B. Alternative Sweeteners, Third Edition, Revised and Expanded. England; Uni-Journal (2001). Available from: $<$ http://books.google.co.id/books? id=aeMH0F5Z4q4C\&dq=Krasse + dan + Newburn\&hl=id\&source=gbs_navlinks _s> (diakses juni 2011)

16.Blum HL. Handbook of Health Behavior Research IV. Worldspress e-journal and e-book; 2011. p. 297.

17.Chandra S. Textbook of operative dentistry. $1^{\text {st }}$ ed. New Delhi: Jaypee; 2007. p. 9.

18.Nasruddin J. Eating your way to good dental health. Jakarta; dental journal; 2005. Available from: $<$ www.mda.org.my $>$ (diakses Januari 2010)

19. Wiratmo H. Pengaruh Konsumsi air minum terhadap terjadinya karies di daerah pantai dan pegunungan di kabupaten Takalar. Bandung; Jurnal medika kesehatan gigi; 2010.p.46. 